every four years. The last meeting of the Ornithological Congress in England was at the Imperial Institute, London, in 1905, with Dr. R. B. Sharpe as president. In 1910 it was held in Berlin, and it was proposed to hold the 1915 Congress at Sarajevo, Yugoslavia, but in the meantime the War broke out and no further Congress was held until 1926, when, mainly through the efforts of Dr. Ernst Hartet, keeper at Tring Museum, it was resumed at Copenhagen. Preliminary arrangements have already been made for the 1934 Congress at Oxford, and the Rev. F. C. R. Jourdain, of the British Ornithologists' Union, has been elected honorary secretary. Dr. P. R. Lowe, of the British Museum, has been elected chairman of the executive committee, which includes Lord Rothschild, Lord Scone, Dr. C. B. Ticehurst, Dr. Sclater, and Messrs. Stuart-Baker and H. F. Witherby, president of the British Ornithologists' Union.

Dexegates to the Congress will include the leading ornithologists from all parts of the world, particularly Australia, New Zealand, Argentina, Brazil, Japan, India, the United States, Canada, and all European countries. The problem of oil pollution of the sea, whereby hundreds of sea-birds, including many rare species, are annually being destroyed especially on the North Atlantic shores, will be a prominent feature of the section on bird protection, while the practice of 'ringing' as a means of tracing bird migrations will also be discussed. One of the most important items, however, is the project for founding an Institute of Ornithology at the University of Oxford, which it is hoped to develop out of the existing scheme of research in economic ornithology at Oxford, the grant for which expires in September, 1933. The new institute is intended to be a national centre for field ornithologists as the British Museum is for systematists. $£ 8,000$ is needed to run the Institute for a preliminary five years while steps are being taken to put it on a more permanent basis. An appeal will be made not only for funds but also for gifts of books, field notes and photographs, etc., for equipping it. It is also proposed to arrange at least one long excursion to study British bird life, and South Wales will probably be chosen as the area to visit though several shorter excursions are to be made. The lectures and papers are to be given in English, French, German and Italian.

\section{New Buildings of the University of London}

UNDER the title "The New Buildings for the University of London" (The Dryden Press) Mr. T. LI. Humberstone has published a 'symposium', in which a contribution to NArure (July 9, 1932, p. 49) is reprinted, followed by an explanation of the plan of the proposed buildings by the architect (illustrated), and expressions of opinion from architects and laymen and a supplementary note by Mr. Humberstone himself. It will be remembered that $\mathrm{Mr}$. Humberstone in his original article, after a brief summary of past difficulties and controversy connected with the accommodation of the University, expressed certain misgivings in regard to the suitability of the proposed buildings, especially in relation to the provision for scientific research. These views are now supplemented by critical comments from others. Prof. S. D. Adshead, professor of town planning in the University, for example, remarks that "if only on account of its rigidity-the system must fail". In his supplementary note, Mr. Humberstone reverts to his previous contention that the University buildings should make provision for an institute for scientific research, pointing out the unsuitability of the scheme, as well as the unnecessary expense involved, for the purpose, and discusses the bearing of the conception of the University as a federation upon the development of facilities for research as part of the equipment and organisation of the University, as distinct from its constituent colleges.

\section{San Diego Museum}

Local patriotism flourishes perennially in the United States. As part of a campaign "Know your San Diego", Mr. Malcom J. Rogers, curator in anthropology in the Museum of San Diego, has recently broadcast a lecture, in which he gave an account of the origin and growth of the collections. The nucleus of the museum was an exhibit at the Panama-California Exposition of 1915-16. The organisers of the exhibition, in consultation with officials of the U.S. National Museum, spent some three years in getting together a collection to illustrate the origin, racial types and culture of man. Expeditions were sent to Asia, Africa, South America, the Pacific and the Arctic for material and the collections then made were housed in the only permanent building in the exhibition, the California Quadrangle, which is still its name, as it had been intended from the first that what, it was hoped, would be a unique educational exhibit, should "not be a thing for the moment, but an enduring institution for the benefit of the people of San Diego and its visitors". At the close of the exhibition the collections were transferred to a permanent Museum Association in trust for the people of San Diego. Dr. Edgar L. Hewett, of the Archæological Institute of America, who had been responsible for this department during the exhibition, was made the first director of the Museum. Constant additions have been made to the collections, which are now so extensive that it is possible only to show the exhibits in rotation. They are arranged departmentally, to illustrate man's origin (by casts), physical types, and culture in the past and present. The archæology of Central America and the Mayas is abundantly illustrated, the most striking and best-known buildings and monuments being represented by replicas. The pride of the Museum, however, is the collection from the southwestern States and, more particularly, that from Southern California, the latter being unique and beyond question the most complete in existence

\section{Bird Life on Ailsa Craig}

A REPorT on bird life on Ailsa Craig was submitted to Ayr County Council on May 30, the Earl of Glasgow presiding, following a communication from the 
Scottish Office. The report, prepared by Lieut.Commdr. G. H. Hughes-Onslow, Barr, and Mr. T. Smith, Maybole, recommended that protection be given to guillemots, razor-bills, puffins, kittiwake gulls, and oyster catchers, and also to black guillemots, stormy petrels and fulmar petrels, which have been observed in pairs on the Craig but have not yet nested there, although they have nested on the neighbouring mainland. Protection was not recommended for solan geese or gannets, the stock of which is sufficiently large, nor for the greater blackbacked gulls, lesser black-backed gulls, herring gulls, and cormorants, which are so numerous all around our coasts and so destructive to fish and other life as not to merit protection. Regarding the practice of shooting birds from boats, the reporters agreed with the Secretary of State for Scotland that prohibition could not be enforced. The practice, however, should be discouraged. The comparatively few eggs collected by the tenants on the island has no effect on the bird life. The report was adopted for submission to the Scottish Office.

\section{Peterhead Sealers and Whalers}

Is the January-February number of the Scottish Naturalist, No. 199, 1933, Dr. Robert W. Gray continues his very interesting account of "Peterhead Sealers and Whalers : A Contribution to the History of the Whaling Industry", begun in 1932 (SeptemberOctober). Peterhead first sent a whaling vessel to the Greenland Sea (the "Greenland" of the old sealers and whalers, the Spitsbergen Sea, the ocean between Greenland and Spitsbergen) in 1788, and a Greenland whaling ship sailed out of Peterhead for the last time in 1893. Dr. Gray, whose grandfather and father both commanded whaling ships, possesses original log-books containing a large amount of reliable information as to the whaling in the latter portion of this period and has gathered together data from many sources relating to the earlier years, beginning with the tiny Robert, the pioneer vessel. Up to the year 1814 the fishery had been pursued generally in the more northerly regions, but after this the boats began to explore southwards. From 1825 the Peterhead ships went mostly to the Davis Straits and the whales of the Greenland sea were left alone for a time. In 1837 the whalers returned to the north and both northern and southern fishing was continued, the northern fishery in some years proving very successful. A great deal is to be learned by reading this article, the present portion going up to the year 1874 . In that year, according to the logbook of the Eclipse it was an open season, northerly winds prevailed in April, May and June, there was a strong south-westerly drift and the edge of the ice lay far west. The ice was drifting south at the rate of twenty to thirty miles a day, and at the end of the voyage it was estimated that more than 300,000 square miles of ice drifted south out of the Arctic Ocean in three months.

\section{Electrical and Rubber Equipment on the Farm}

THE supply of electricity to rural areas is continually extending so that increasing numbers of farmers are interested in this alternative method of lighting their farm buildings and conducting power operations in and around the homestead. In these circumstances a visit to a farm carrying a good equip. ment of the ordinary machinery as well as a complete electrical installation gives an excellent view of the possibilities. At Rothamsted, a thoroughly up-to-date electrical equipment has been supplied by the General Electrical Co., Ltd., and means are provided for making exact comparisons of electricity and oil as sources of power for farm operations. On June 19 a demonstration of the plant was arranged for a party of experts and farmers. The visitors were conducted round the farm buildings and examined a large number of power operations in progress, the motors ranging from 20 h.p. down to $\frac{1}{2}$ h.p. according to the nature of the work. A very complete and efficient lighting system was demonstrated and electricity was in use for water heating, sterilising, and various other stationary processes. First-hand information with regard to the engineering details and performance of the machinery was also available. A demonstration of a number of uses of rubber on the farm was arranged by the Dunlop Rubber Co., Ltd. Various types of rubber flooring for stables, cowsheds and piggeries were on view. The visitors also examined the performance of heavily laden farm carts equipped with low-pressure rubber tyres and rubber-tyred tractors at work on the arable land.

\section{Scottish Marine Biological Station, Millport}

THE Scottish Marine Biological Association's annual report on the work of its laboratory at Millport on the Firth of Clyde, for the year 1931-32, has recently been issued (Glasgow : $185 \mathrm{St}$. Vincent Street). The Association is to be congratulated on the large measure of success which is attending the important though highly specialised researches upon which its small staff of four is actively engaged. Their work has received high commendation from H.M. Development Commissioners and other interested organisations well qualified to assess its value. Over and above the important work on Calanus finmarchicus (see NatuRE of June 10, p. 843) which is being done, the results of a considerable number of other researches carried out by the station staff and visiting workers have been published in the course of the year. Chief among these must be mentioned several important memoirs by Miss Marshall, Mr. Orr, and Dr. Nicholls, embodying the results of their researches while members of the Australian Great Barrier Reef Expedition of 1928-29. In common with all other organisations in Great Britain and other countries, the Millport Laboratory has been adversely affected by the present economic depression. The block grant originally voted to it by H.M. Treasury-on condition that a proportional sum be raised independently from other sourceswas considerably cut down, and the local contribu-

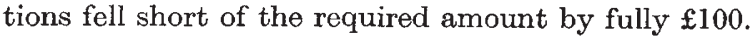
It is greatly to be hoped that the state of financial stringency which still exists will not be allowed unduly to restrict the activities of this and similar institutions. 